\title{
Creativity and Remote Teaching in Pandemic Times: From the Unpredictable to the Possible
}

\author{
Mônica Souza Neves-Pereira
}

University of Brasilia, Brazil

\begin{abstract}
The COVID-19 pandemic imposed a new agenda for humanity. In a very rapid and improvised way, we were invited to give new answers to everyday practices and experiences, challenged by a context of social isolation unprecedented for a globalized world. The resources that allowed us to build and innovate in the face of such a scenario were mostly derived from communication technologies. In a very short time, the contexts of work, schools, social practices migrated to computers' screens, cell phones, and so on, transforming them into learning tools mediating social relations. People have long used technology to study, to work and to relate to each other. With COVID-19, we need to face unpredictable situations, requiring rapid adaptation, and the urgent creation of remote relational contexts as a way to respond immediately to the challenges and problem situations emerging from the pandemic. In this article, the remote teaching experience of an undergraduate class at a Brazilian university will be discussed, considering the students' self-perception about the dynamics of their creative processes in this period. Through a "Free Talk" session carried out in an undergraduate class, we will discuss technologies and
\end{abstract}

teaching, differentiated educational practices and their impacts on the learning processes and, in particular, we will reflect on creativity, the fragility of its development in difficult times and its power to deal with unpredictability, transforming human paths into new possibilities.

\section{KEYWORDS:}

teaching technologies, remote teaching, human development, creative processes

\section{Article history:}

\section{Corresponding author at:}

Received: June 4, 2021

Received in revised from: July 5, 2021

Mônica Souza Neves-Pereira

Accepted: July 12, 2021

E-MAIL:monicasouzaneves@gmail.com

ISSN 2354-0036

DOI: 10.2478/ctra-2021-0006 
The COVID-19 pandemic imposed a new agenda for humanity. In a very fast and improvised way, we were invited to give new answers to daily practices, experiences and lives, challenged by a context of social isolation unheard of in a world as interconnected and globalized as ours. The resources that allowed us to deal with the unpredictability imposed by such a scenario were mostly derived from communication technologies and human creativity. In a very short time, the contexts of work, educational processes and social interactions have migrated entirely to the screens of computers, smartphones, tablets, and online platforms, transforming these technologies into training tools, work tools and mediators of social relations. In short, we have been saved by the cyberspace that dominates postmodernity, which has become the habitat of almost all human interactions, information and knowledge exchanges.

With regard to educational processes, countries that have formally instituted education systems were forced to close the doors of their schools and universities, dealing with severe losses related to the development of their populations (Reimers \& Schleider, 2020; UNICEF, 2020). After the initial scare, world movements immediately emerged seeking to understand and analyze the context of the pandemic and its relationship with educational processes, in an attempt to recreate some kind of "normality" for the education of human beings. Important organizations such as the UN, UNICEF, OECD and universities from different countries, joined together in the production of educational public policies, distance education management programs, instructional material to assist virtual interactions, in addition to seeking elements that would allow for understanding the pandemic and its impacts on public health, society, economy and politics.

The psychological and educational contexts, due to their human, social, political and economic relevance, were areas that quickly sought to adapt to a world in isolation and transformation. With the support of scientific research, productions emerged advising on how to deal with the pandemic, its impacts on public health, mental health and education (Crawford et al., 2020; Shadmi et al., 2020; UNICEF, 2020). Experiences with distance education, investigated and extensively tested in recent decades, became extremely relevant for the resumption of different types of teaching through communication technologies, web applications, online platforms, and other cyberspace resources (Barreto \& Rocha, 2020; Monteiro, 2020; Wenczenovicz, 2020). Through different designs and alternative paths (Crawford, et al., 2020) actions to "adapt" to the new context were initiated, with instructions, guidelines and legislation created to preserve and maintain basic activities of a society. Unfortunately, this was not the reality in some Latin American countries.

Analyzing the Brazilian paths in meeting educational demands, as a result of the humanitarian crisis, is our central interest in this paper. We are going to discuss about the remote teaching experiences adopted in Brazil, seeking to understand this "pandemic pedagogy" and its possible effects on the learning and creativity of higher education students and teachers. We will use, by way of illustration, data constructed in a meeting called Free Talk ${ }^{1 *}$, held with a teacher and students from different undergraduate courses, at a Brazilian public university, covering the themes of (a) isolation and social interactions, (b) remote teaching and learning and technological resources, and (c) creativity in times of crisis. The "Free Talk" session took place at the end of the second half 
of 2020, at a distance, on the initiative of a research group (coordinated by the author of this paper) who had been developing work in the psychological and educational areas. It is our interest to discuss how the unpredictability of human existence puts us in front of multiple (im)possibilities and how we can transform what is possible into powerful acts of human development, learning and creation.

\section{LIFE AND EDUCATION IN PANDEMIC TIMES: THE BRAZILIAN SITUATION}

Humanity has been using technology to study, work and connect for a long time. Social interactions and practices have been progressively migrating to online communication systems, virtual platforms, applications and social networks, changing the scenario of relating with peers, with one's work, education and everyday living. Realities such as distance learning, home office and virtual interactions are beginning to be the rule, in a world as connected as ours. In addition to getting information through online media, shopping on specialized sites, using all public and private services via the internet, dating and marrying people we know from relationship apps, the pandemic challenges us to study and work in the same way. The arrival of Coronavirus pushed us into the reality of an existence lived entirely online, profoundly transforming our understanding of the world and placing us in a zone of uncertainty that, we believe, will still last for a long time. We human beings need time to assimilate so many changes. The personal, psychological and social disorganization promoted by the pandemic took us off the streets, physical and public spaces, work, school, meeting others and placed us in limited areas far from our peers, limiting our dialogues and communications. For a gregarious being, like the human subject, it was an abrupt change that will certainly show its effects in the near future.

Brazil has been dealing with COVID-19 in a very unfavorable and inefficient way. Under the tutelage of a government in denial of science, human rights and common sense, which operates based on a neoliberal ideal and a proto-fascist narrative, it would be impossible to expect that a pandemic would be treated with seriousness, commitment, effective actions, support, protection and support to the population, as it occurred in other countries around the world (Melo \& Cabral, 2020; Py, Shiota \& Possmozer, 2020). The Brazilian government has been leading, in the public square, the greatest global disregard for the pandemic and for its population, which perceives itself as left to its own devices, hostage to a government that works, day to day, in favor of the spread of the virus, contributing to almost half a million deaths so far.

The chaos prevailing in Brazil is exposed in Brazilian and foreign newspapers, with ample documentation. Hunger has returned to ravage the poorest people, who die every day without social, economic, or health protection. This unprecedented tragedy has affected (and continues to affect) all Brazilians, even those who support this genocide in the name of the indefensible. 
All instances of Brazilian society are deeply wounded by so many deaths and tragedies. Schools and universities have also been the stage of loss, pain, mourning and much struggle.

With the beginning of the quarantine in Brazil, which has already lasted more than a year, the public and private education systems suddenly found themselves challenged to find ways out of this complex situation, without the support of the public authorities. At first, school activities were suspended throughout the country, without any federal, state or municipal management of the pandemic crisis in the educational area. Gradually, schools and universities began to rethink their activities, organizing themselves for a possible resumption of classes, even if remotely, on their own.

It took some time before the Brazilian Ministry of Education expressed itself, through an Ordinance (MEC, 2020), and established distance and remote learning on an exceptional basis and for a fixed time, under the responsibility of educational institutions, as an alternative to keep the system running. After a turbulent change of command in the Ministry of Education, motivated by political fights in the government, a document emerged at the end of 2020 with a "proposal" of governmental actions for Basic Education, in the face of the COVID-19 pandemic (MEC, 2021). This document deals mainly with some financial resources and minimum provisions to be offered by the Federal Government to Basic Education, excluding Higher Education. There is, in this material, no pedagogical planning, no guidelines for teachers, no reflections on teaching and learning in the context of a pandemic, no considerations about the impacts and consequences of remote teaching in a country where the majority of the population lives on the poverty line. In summary, the federal government and the Ministry of Education did little to help schools, universities and teachers deal with the challenges of remote teaching in the pandemic. On the contrary, they continued practicing their necro-policy of destroying the education systems, especially higher education, by taking away decent working and functioning conditions.

Even dealing for a long time with distance learning (ABED, 2020), Brazilian schools and universities had to migrate their pedagogical practices to remote teaching modes, without prior planning and on an emergency basis, to meet the students who had to leave their classrooms and stay isolated, at home. At the end of the first year of the pandemic, different styles of remote teaching emerged to reconnect children and young people with their classrooms, their teachers and the school world. Remote teaching was an emergency option that required immediate adaptation, with little planning and affecting the developmental processes, learning and creativity of students and teachers. Creative processes, understood here as human practices, generated in social interactions and with the help of cultural mediation, were significantly affected by the transformation of school modes of operation.

Considering that remote teaching is not distance learning (Barreto \& Rocha, 2020; Monteiro, 2020; Wenczenovicz, 2020), what we are experiencing in Brazil at the moment are not systematically planned actions, with the support of educational technologies, with the elaboration of adequate pedagogical materials and with agendas that intersperse online and face-to-face learning moments for students and teachers. What we are experiencing are improvised remote teaching actions, 
organized in a hurry, with the available resources, without planning or governmental support, using already existing platforms, several applications, smartphones, with students without internet access and without pedagogical materials to support the teachers, who feel they have no guidance whatsoever in their pedagogical practices. The Brazilian education system was not designed to operate in the distance education modality and this, in fact, did not happen. Our reality is that remote learning is planned and executed by each educational institution and its educators, who try to remedy the difficulties and damages arising from an atypical public health context. At every university, at every school, people work in a different way. Even academic calendars are different. This disorganization clearly reflects the absence of public management while Brazil lives under the command of the current (dis)government.

This sad scenario presents parents, students and educators with numerous questions about the consequences, in the medium and long term, of this abrupt transformation of the teaching modality for students of different ages, needs, demands, and from diverse socio-cultural and economic backgrounds. We can go further and ask: what are the consequences of a disorganized and precarious remote pedagogical practice for human development, learning and creativity? In this article, we do not intend to investigate the damage of the pandemic to the Brazilian educational system. Our proposal is to raise discussion points on these themes that can mobilize and motivate future research, not only in Brazil, but in other nations as well.

In this article we will use, as an illustration, data from the remote teaching experience of an undergraduate class at a Brazilian university, considering the processes of students' self-perception about the dynamics of their creative processes and learning during this period. Through a "Free Talk" session held in an undergraduate class at a public Brazilian university, where students talked about their perceptions, feelings, difficulties and facilities in their learning and creativity processes, during the second semester of the year 2020, we will discuss technology and teaching, differentiated educational practices and their effects on learning processes and, in particular, reflect on creativity in difficult times and its power to deal with unpredictability and transform human paths into new possibilities.

\section{LIVING, LEARNING AND CREATING IN REMOTE MODE}

Information technology is allowing us to live in difficult times, giving continuity to our tasks, commitments and projects. We are together facing a fatal virus, but we are not in the same boat. The ways of coping with the pandemic will be different for different social groups (Couto, Couto \& Cruz, 2020; Monteiro, 2020). Those who have economic resources will have state-of-the-art tools and technologies to help them at this time (Crawford et al., 2020; Couto, Couto \& Cruz, 2020). Those living in poverty will not have this support. Their lives will be much more difficult, including their educational experiences. 
What has most marked the experiences of studying, learning and creating, in remote mode, in Brazilian educational institutions is precisely the heavy hand of social inequality that excludes students from the educational process for not having the minimum requirements to access a remote education. There are studies (Cooper, 1996) that argue that vacations usually affect students' learning processes, promoting loss of relevant content. According to Cooper (1996), students lose the equivalent of one month of subject content, the longer the vacation or the child's absence from school. It is not difficult to imagine these losses during a pandemic, social isolation and the insertion of an improvised remote education, where classes are rare, taking place once a week and in technological contexts with no access for the poorest population. Brazilian students have been living this situation for more than a year. For many, it has been a year and three months since they have had any classes, since they have been out of school, due to an absolute lack of access to the necessary technologies and the inertia of an irresponsible government. How to deal with this situation?

There are those who bet on creative possibilities in conducting a remote teaching, considering that teachers and students, with access to quality internet, teaching platforms and social networks, become producers of "school or academic" contents, enriching the virtual teaching practices (Couto, Couto \& Cruz, 2020). It seems feasible that, under ideal conditions, the experience in cyberculture could allow for quality educational exchanges. However, this is not the reality of a large part of humanity, including many in Brazil. Contexts of precariousness, exclusion and lack of resources will make the task of creativity much more difficult with regard to remote teaching and educational processes at a distance. They will also greatly hinder the development of this creativity in the daily lives of the subjects. A difficult task, however, is not an impossible one.

In this article, we will listen to Brazilian students who are living this experience, some from privileged socioeconomic backgrounds, others (the majority) in a situation of generalized deprivation. These distinct groups of students attend the same courses in Brazilian public universities, dealing with a universe of daily unpredictabilities that challenge them to cope with their academic and survival tasks. At a time when the pandemic has taken hold and everything has changed for human beings, unpredictability has started to call the shots, and it is only by listening to its subliminal and almost inaudible words that it has been possible to create creative possibilities that allow us to resist and live in difficult times. Responding creatively to this scenario is not an easy or romantic task. It is something that demands all kinds of investments, support, trust, social and material conditions, welcoming contexts, dialogue, and autonomy (Glăveanu \& Neves-Pereira, 2020; Neves-Pereira, 2020)

Creativity is power, it is migrating from the possible to the real, it is constructing bridges between desire and realization, it is a movement that demands material conditions, minimum contexts for its occurrence and cooperative social interactions. Creating is a social act, it needs the other, dialogue, a dimension of materiality, action, symbolic and culture, as catalyzing elements in the exercise of creation. The dynamics of creation is dialogical, it requires the voice of the other in each of us, in permanent dialogues, in oppositions, in conflicts and movements (Glăveanu, 2014, 
2015; Glăveanu \& Neves-Pereira, 2020). Even though we don't share a romantic vision that sees creativity as the child of necessity and therefore the savior of humanity when in crisis, we believe that it is still a viable way for humans to transform themselves and the world in order to deal with their difficulties and construct a healthier and happier life. Many times, this path is arduous, as it has been at this moment for students and teachers in Brazil, and in many other countries in the world, who count on little support and adequate resources to learn and to create. Limitation and unpredictability, however, also have their power and can generate the new.

The pandemic pedagogy that emerged in Brazil, in the form of improvised remote teaching and under the responsibility of the educational institutions, teachers and students, has been trying to manage the difficult task of teaching, promoting learning and human development, in a country of inequalities (Barreto \& Rocha, 2020; Couto, Couto, \& Cruz, 2020). Soon after the resumption of teaching activities in Brazil, it was very clear that we would not count on the support of the Federal Government in this endeavor, a situation that condemned hundreds of thousands of students who do not have access to the Internet and do not have computers at home to being effectively excluded from school. In the case of public universities, the scenario was no different. Many students dropped out of their courses for not having the resources to continue their studies, others remained, hard at work, taking classes and producing their homework on cell phones (Monteiro, 2020). In addition to mourning the enormous human losses from the virus, our students have also had to deal, for the most part, with all sorts of difficulties and privations to maintain their studies, among them rapid impoverishment, the return of hunger to the country, the absence of financial support for the poorest, the collapse of the health system and the digital exclusion that isolates $54 \%$ of Brazilians from access to the Internet (Couto, Couto, \& Cruz, 2020).

Thinking about a pandemic pedagogy (Barreto \& Rocha, 2020; Duarte, 2011) requires including human aspects linked to the teaching and learning processes that need to be reviewed and, sometimes, recreated in contexts of profound difficulties, such as those we are experiencing at the moment. Among these aspects, it is important to highlight: (a) isolation and social interactions, (b) teaching and learning in remote mode and technological resources, and (c) creativity in times of crisis.

Based on data collected in a "Free Talk" session with students from different undergraduate courses at a public Brazilian university, where the aspects listed above were prioritized in the dialogues constructed between teacher and students, we will discuss these topics in an attempt to understand the experiences of these subjects, in remote teaching, in the COVID-19 pandemic in Brazil. Our intention is to start from the contexts of unpredictability and precariousness that the virus has placed us under, evaluating the movements of teachers and students in remote teaching, in search of understanding and co-creation of new individual and collective possibilities in times of crisis. The focus on the emergence of creative actions emerges as a central element in this discussion. 


\section{REMOTE TEACHING AND CREATIVITY: THE STUDENTS' EXPERIENCE}

In the year 2020, remote teaching began in public universities. The modes of operation of this teaching modality varied from institution to institution, as did the preparation of school calendars, availability of technological resources and styles of teaching and pedagogical support suitable for entering this territory. What has been observed is a multiplicity of teaching scenarios, with academic semesters being offered late, with a minimum workload and the challenge of carrying out teaching, research, extension and internships at a distance. For teachers and students, it has been an absolutely new adventure, which has placed us in a zone of unpredictability, demanding creative solutions to unexpected problems that have emerged all the time. We have never needed creativity so much. It has never been so hard to be creative.

At the end of the first year of remote teaching in Brazil, in 2020, in a public university, the author of this article decided to hold an informal meeting via Google Meet, with undergraduate students from different courses, to talk about the pandemic, life, emotions, feelings, remote mode studies, learning processes, reactions to the various problems that arose for everyone, highlighting how creativity has helped deal with the unpredictable. This meeting, henceforth called "Free Talk", aimed at mapping future research themes and ended up generating a body of data of the greatest relevance for us to understand how we are living this very difficult moment, especially in virtual learning spaces. The group of participants decided, by consensus, to videotape the meeting for future studies. Part of the data emerging from this "Free Talk" will be used in this text, only as an illustration, enriching the dialog under construction in this article. All participants authorized the use of the data by any of the subjects present at the informal meeting.

In the "Free Talk" session, 32 students from different undergraduate courses participated, together with the researcher teacher, with the initial purpose of having an informal talk about the themes already listed. Of the 32 students present, 18 participated at the invitation of the teacher and their classmates. The remaining 14 students had research links with the professor. The meeting took place on October 20, 2020, via Google Meet, from 4 to 6:30 pm. Table 1 characterizes the participants, as follows:

The data in Table 1 situate the participating students at different socioeconomic and cultural levels, significant for facing the pandemic and remote education. The reality of Brazilian public universities nowadays registers a significant increase of socioeconomically less favored students, as a result of compensatory social inclusion projects implemented in the last decades by leftwing governments. The historical situation of social and economic inequality in Brazil, as well as background issues such as discrimination against the poor, black and marginalized populations, have left deep gaps in the Brazilian social fabric, preventing young people from disadvantaged classes from rising professionally or participating in the country's scientific and technological development (Aprile \& Barone, 2009). 
Table 1. Data from the participants in the "Free Talk" session

\begin{tabular}{|c|c|c|}
\hline \multicolumn{2}{|c|}{ Participants' average age } & \multirow{2}{*}{$\begin{array}{l}A=18.9 \text { years } \\
\text { Women: } \\
N=20\end{array}$} \\
\hline $\begin{array}{l}\text { Number of participants: } \\
\qquad \mathrm{N}=32\end{array}$ & $\begin{array}{l}\text { Men: } \\
\mathrm{N}=12\end{array}$ & \\
\hline $\begin{array}{l}\text { Data from the teacher who } \\
\text { organized of the "Free Talk" session }\end{array}$ & \multicolumn{2}{|c|}{$\begin{array}{l}\text { - Teacher with a PhD in Psychology } \\
\text { - Over } 15 \text { years of experience in teaching, research and extension, at the undergraduate } \\
\text { and graduate levels } \\
\text { - Active professional who has been working in remote mode since March } 2020 \text {. }\end{array}$} \\
\hline Participating students' courses & $\begin{array}{l}\text { - Education }-7 \\
\text { - Psychology }-16 \\
\text { - Communication }-3 \\
\text { - Social Sciences }-2\end{array}$ & $\begin{array}{l}\text { - Nursing }-2 \\
\text { - Civil Engineering }-1 \\
\text { - Statistics }-1\end{array}$ \\
\hline Participants' socioeconomic pattern & $\begin{array}{l}\text { Students belonging to the } \\
\text { middle class (Brazil pattern) with } \\
\text { a monthly family income above } \\
R \$ 3,000.00 \text { or } U \$ 574.01)\end{array}$ & $\begin{array}{l}\text { Students belonging to the middle class (Brazil } \\
\text { pattern) with a monthly family income below } \\
\qquad \text { R\$3,000.00 (or U\$574.01) }\end{array}$ \\
\hline $\begin{array}{l}\text { Access to communication } \\
\text { technologies: internet, computers, } \\
\text { smartphones, tablets, etc. }\end{array}$ & $\begin{array}{l}\text { Easy access to communication } \\
\text { technologies: } \\
20\end{array}$ & $\begin{array}{l}\text { Difficulty of access to communication } \\
\text { technologies: } \\
12\end{array}$ \\
\hline
\end{tabular}

\section{ISOLATION AND SOCIAL INTERACTIONS}

In the "Free Talk" session with the students, the theme of isolation and limitation of social interactions was deeply felt by all participants. We are a species that constitutes itself as a subject in interaction with the other, in dialogue, in consensus, in dissent, in conflict, in cooperation, in encounters (Valsiner, 2014; Vygotsky, 1978, 2012). We construct ourselves as we construct the world and culture, always through the eyes of the other. In this two-way, dialogical dance, the Self-Other meet, bump into, affect and transform each other, mediated by cultural messages, in a material world steeped in culture, driven by an irreversible time that marks our life trajectory (Valsiner, 2014). Our human development process is pure creativity. We are invited to reinvent ourselves at every moment of existence, only because there is another who mirrors, reflects, mediates, challenges, motivates and affects us (Cornejo, Marsico, \& Valsiner, 2018; Glăveanu, 2014, 2015; Neves-Pereira, in press). Regarding learning processes, Vygotsky (1978) was accurate in saying that learning is the internalization of culture, a process dialectically linked to the human development of our species. In the absence of learning, in the absence of the other who is the mediator of culture, the processes of human development are impeded. This is a good start to think about human beings that were forced to isolate themselves, suddenly, because of a pandemic. 
In our teacher-student meeting, where we talked freely about the pandemic, isolation and social interactions, the first line that emerged was: "it's one thing to interact over the Internet because life, today, is like that; it's another thing to interact over the Internet because I have no other option" (Subject 10). This line suggests severe damage to interactive processes, even in times of "normalized" virtual contacts. Nowadays, young people communicate much more virtually than face-to-face, but this virtuality has never excluded face-to-face interaction. Being with the other, by means of communication technologies is not a problem, as long as one can be with this person, in person, when desired. The pandemic changed this scenario, preventing face-to-face contact. This interdiction seems to be suffered more than one could imagine, as reported by the participants of this meeting: "knowing that my boyfriend is close to me and not being able to be with him, that is a kind of death" (Subject 4); "I feel the need to be with my grandmother, physically. She doesn't use WhatsApp" (Subject 11).

The students who participated in this meeting expressed themselves in relation to isolation and social interactions in very similar ways. It is important to highlight that the participants of this meeting are young, with an average age of 18.9 years, beginning their undergraduate studies, full of expectations, desires and wishes that were prohibited by the pandemic. Table 2 presents the main discourses of the students on this theme (Table 2):

Table 2. Students' views about isolation and social interactions

\begin{tabular}{ll}
\hline \multicolumn{1}{c}{$\begin{array}{l}\text { Students' speeches about isolation and social interactions } \\
\qquad N=32\end{array}$} & n \\
\hline Social isolation is very bad for me & 19 \\
\hline I feel alone, powerless, anguished & 18 \\
\hline I feel bad, physically, for being far away from people & 11 \\
\hline I need my friends close to me & 11 \\
\hline I cannot help my friends and family to protect them from the virus & 9 \\
\hline I am very afraid of the future in Brazil & 9 \\
\hline I have been silenced. The pandemic has hijacked my voice & 7 \\
\hline I feel fear and sadness for the people who are dying of COVID & 7 \\
\hline My family does not support me in my loneliness & 6 \\
\hline
\end{tabular}

In this group of participants, only one subject presented a way out of the problem of social isolation, when he reported: "I established a virtual support group with four colleagues that gave me support during the pandemic. I don't know what would be of me without this group" (Subject 28). At this point of the students' report, we begin to discuss creative actions to face the difficulties repeated in other themes. From the beginning of the "Informal Talk", reports emerged about a kind of creativity that was called by the students $(n=12)$ "adaptation or survival creativity" resulting from a borderline and frightening context that imposed itself on all.

The negative impacts of social isolation in the pandemic are glaring in the speech of these students. Everyone seems to be affected by isolation, but students at socioeconomic risk are more 
affected. Distanced from the university, from their classmates, friends and professors, these subjects have lost almost all opportunities for inclusion and social interaction, since they are also deprived of internet, computers and other communication technologies (Berg, Vestena \& Costa-Lobo, 2020). In our meeting, we had reports such as: "I don't have a computer" (Subjects 3, 7 and 9), "I don't have money to pay for internet" (Subjects 23 and 32), "I am the most isolated person in the pandemic" (Subject 3), which puts these students in a harsher form of isolation, when compared to the others. This social and economic isolation generates a list of harmful feelings and emotions, turning the existence of these subjects into a profound experience of sadness, a fact that affects and impairs their academic performance and learning. The creativity of these students, deprived of economic and technological resources and isolated from their peers, is also affected (Castillo-Vergara, 2018), generating expressions such as: "to be creative for what? I have no motivation to create" (Subject 23).

\section{REMOTE TEACHING AND LEARNING AND TECHNOLOGICAL RESOURCES}

Remote teaching in Brazil has presented ambiguous results, highlighting the challenges that educators, teachers and students alike had to assume in the daily life of distance learning (Hodges et al., 2020). For instance, extreme tiredness and exhaustion emerged as key themes (Saraiva, Traversini, \& Lockmann, 2020), both in the teachers' and students' speeches. In the "Free Talk" session, which has been illustrating our discussion, fatigue dominated the students' speeches, accompanied by other detrimental factors to the learning and teaching processes. Table 3 presents what the students said about teaching and learning in remote mode and technological resources.

Table 3. Students' views about teaching and learning in remote mode and the technological resources

\begin{tabular}{|c|c|}
\hline $\begin{array}{l}\text { Students' speeches about teaching and learning in remote mode and the technological resources } \\
\qquad \mathrm{N}=32\end{array}$ & $\mathbf{n}$ \\
\hline Remote teaching has made me very tired & 26 \\
\hline I had access to quality technological resources in remote learning & 20 \\
\hline I could not adapt to remote teaching & 17 \\
\hline Remote teaching hindered my learning & 12 \\
\hline I didn't have access to quality technological resources in remote learning & 12 \\
\hline The excess of technologies makes me very tired & 10 \\
\hline Studying by computer breaks my concentration & 9 \\
\hline My personal life has become mixed with my academic life and I don't like it & 9 \\
\hline I had to increase the degree of my glasses because of too much exposure to the computer screen & 7 \\
\hline I get a lot of headaches from remote learning & 6 \\
\hline I was able to adapt to remote learning & 4 \\
\hline
\end{tabular}

Tiredness, exhaustion, lack of concentration and difficulty in learning emerged with high frequency in the speech of the students who participated in the "Free Talk" session, arguments that are already being discussed in the pedagogical and psychological literature (Hodges et al., 2020; Saraiva, 
Traversini, \& Lockmann, 2020). What is apparent, as research and theoretical studies on remote teaching and the pandemic begin to be published, is that the experience of teaching and learning in an improvised and unpredictable manner has a price attached to it. This price, it seems, is exacted on the physical and mental health of teachers and students who are forced to modify their work practices, with no room for negotiation.

At first, it seemed logical that people, used to spending hours surfing the Internet, would feel comfortable to learn and teach through digital technologies. Experience, however, has shown interesting aspects, as young people report deep fatigue in staying too long in front of computer screens, as follows: "remote teaching makes me deeply tired" (Subjects 3, 9, 17 and 32); "the excess of technologies makes me very tired" (Subjects 5, 8, 12 and 23); and "I never thought I would hate my computer" (Subjects 8 and 14). The absence of physical boundaries between personal life and academic life, according to the students participating in the "Free Talk", was also a disturbing element: "I attended classes lying on my bed. This is not university" (Subject 9); "I feel that the university has invaded my home and exposed me to my parents" (Subject 25); "what I hated most about remote education was the mixing of my home and university. The boundaries disappeared" (Subject 19).

From the point of view of results, it would not be prudent to say that remote education has failed in its purposes or reaped more failures than successes. Such an analysis would at this point be frivolous and hasty for two reasons. The first reason has to do with the fact that the world's educational communities had no choice but to use this teaching modality, through available technologies, in the face of the pandemic. The second is related to the existence (still) of few studies and data that allow an analysis of this nature. It is very likely that the remote learning planning actions carried out by different countries have not taken into account all the aspects that would impact these actions (Maia, \& Dias, 2020). Urgency and necessity took precedence over psychological and emotional dimensions, leaving the analysis of the possible human consequences for a second moment. In relation to creativity, the consequences of an improvised remote teaching seem to be more worrisome than encouraging. Creating seems to demand a minimum of social, material and human conditions (Glăveanu, 2014, 2015) that, in times of crisis, become scarce for most people. On the other hand, we are only managing to deal with the pandemic because of the creative capacity of so many other groups and subjects that have been promoting advances of the utmost relevance, such as the super-fast advent of Coronavirus vaccines (Cohen, \& Cromwell, 2021).

\section{CREATIVITY IN TIMES OF CRISIS}

Talking about creativity in times of crisis leads to the obvious. The act of creating has been associated with meeting human needs, both in common sense and in the academic field. Creativity, as the ability to solve problems, is a consensus in science, it is a recognized domain in the field of the psychology of creativity (Kaufman, Glăveanu, \& Baer, 2017; Runco, 1994). The association between creating and problem solving emerged very significantly in the data constructed in the "Free 
Talk" session, which has been illustrating the discussions in this article. In the students' narratives, concepts of creativity emerged that proved dominant and very appropriate for difficult times, such as: "adaptive creativity" and "survival creativity". We will explore these narrative constructions in light of cultural approaches to creativity, seeking to identify emerging potentials and possibilities in the daily lives of these students, characterized by severe challenges.

Understanding the perception of the students who participated in the "Free Talk" about their creativity is relevant to this discussion. In the informal talk, the teacher who was coordinating the activity asked the students how they perceived their creative processes since the beginning of the COVID-19 pandemic. Most of the students $(n=21)$ were adamant that their creativity decreased after the pandemic and during remote teaching. Among these students, all those belonging to the poor socioeconomic classes $(n=12)$ agreed with the decrease of their creativity in the pandemic. In the "Free Talk", narratives emerged, such as: "there is no way to be creative in the middle of tragedy" (Subject 18); "the virus arrived and my creativity went away, at the same time" (Subject 6); "when we face a war, few can be creative" (Subject 21).

For other students, pandemic and remote learning enhanced their creative processes $(n=13)$, challenging them to learn new tasks, develop original skills and explore different activities. Students reported that: "I was challenged to use new technologies, which I had not mastered" (Subject 1), "I developed new talents, like learning to cook and paint" (Subject 15), "I had more time for myself and I needed to occupy it by learning new things" (Subject 11). It is relevant to point out that the students who perceived themselves as more creative in the pandemic belonged to middle-class socioeconomic standards, a context that may have protected them from the precariousness experienced by their peers. Students also belonging to middle-class socioeconomic standards signaled a decrease in their creativity. Four students $(n=4)$ reported that their creativity was not affected by the pandemic.

Table 4 presents the students' main speeches about their creative processes during the COVID19 pandemic and in the face of remote learning.

Table 4. Students' speeches about creativity in times of crisis

\begin{tabular}{lc}
\multicolumn{1}{c}{$\begin{array}{c}\text { Students' speeches about creativity in times of crisis } \\
\mathrm{N}=32\end{array}$} & $\mathbf{n}$ \\
\hline My creativity has diminished because of my tiredness & 18 \\
\hline My creativity has been hindered by social isolation & 15 \\
\hline Remote teaching killed my creativity & 13 \\
\hline My creativity needs motivation to appear & 10 \\
\hline My creativity increased only to enable me to survive & 8 \\
\hline Fear has killed my creativity & 7 \\
\hline Ineeded to learn new things and for this reason my creativity increased & 7 \\
\hline My creativity only comes out when I have to solve problems & 5 \\
\hline
\end{tabular}


Cultural approaches to creativity understand this phenomenon as social, co-determined in SelfOther interactions, occurring in sociocultural contexts where all dimensions are present and active in the act of creating. A complex, systemic and sociocultural vision of psychological phenomena cannot fail to be, also, a critical perspective on these phenomena (Valsiner, 2014). Thinking that creativity is not affected by political, ideological, social, cultural and economic instances, dominant in different scenarios, is a naive attitude or an aseptic practice of science. The students' narratives, presented here as an illustration, show the power of multiple human instances in the act of creating. It is very clear, in the students' speeches, how fear, the imminence of death by a virus, the sudden impoverishment and a government that leaves a population on its own, in the face of a tragedy, are potent elements to inhibit any creative process: "I have no time to think about creativity. I have to get a job to help my parents" (Subject 2); "when you feel so afraid, you can't create anything" (Subject 16); "Brazil has become a hell. I just think about surviving and leaving" (Subject 19).

Students living in socioeconomic risk, considering this small sample, were not able to feel creative at any time. Among the participants, the students who experienced creative experiences, or even the increase of their capacity to create new things, come from another social reality, where financial conditions and support to deal with uncertainties are present a little more frequently. These considerations may be relevant for us to think under which conditions creativity can disappear, even when the situation cries out for it (Castillo-Vergara et al., 2018; Mattson, Mathew, \& Buonincontro, 2021). Creating is the function of human beings, and when these beings are under deep stress and threat, is it possible to create? This premise was present, in the meeting with the students, as a subliminal speech that permeated the entire time of the "Free Talk". It was almost like a collective cry from underprivileged students, saying that it is not possible to create when the risk is enormous.

Two important concepts emerged in the "Free Talk" when students were asked to talk about the characteristics of their creativity. These are: adaptive creativity $(n=7)$ and survival creativity $(n=5)$. Adaptive creativity was described as: "I am creating because I need to adapt to remote teaching and social isolation" (Subject 9); "my creativity has increased, but only to solve problems" (Subject 28). Survival creativity was portrayed as: "I don't even know if I'm creating, I'm trying to survive this madness" (Subject 32); "I create to survive the loneliness of social isolation" (Subject 17). In the "Free Talk", the students named a very specific type of creation: everyday acts, restricted to the realm of adaptation, problem solving and survival, with a limited scope and breadth, without much effort or motivation on the part of the creators. Interestingly, perceiving themselves as creative or not, the students understood that the possible creativity, at this moment, would be directed towards survival and adaptation to the pandemic and its consequences.

This creativity, associated with human adaptation to the world and problem solving, has been of utmost relevance to humanity. Mattson, Mathew, \& Buonincontro (2021) conducted a study where they investigated journalistic articles, in different media, that reported varied creative actions performed by ordinary people during the pandemic, from a cultural view of creativity. Their results also highlight the predominance of creative adaptive actions and report negative 
impacts of the pandemic on creative processes. The Coronavirus pandemic may have brought, to the field of creativity, a unique research possibility that will allow us to investigate how we create in times of crisis and life risk. This unique situation can show us particular ways for the development of creativity, this human function that is allowing us to survive an opportunistic virus and that, perhaps, has peculiar ways of expressing itself in critical situations. It is a research opportunity that we cannot miss.

\section{CONCLUSION}

Times of crisis foster creativity. We know this from telling our own story, as a species. However, creating in difficult times seems to have its own specificities. Suffering, fear, poverty and the risk of life take away almost everything, including the motivation to create. On the other hand, some individuals manage to innovate and find different ways, even immersed in the pains of the world. In fact, we are not in the same boat in the face of this pandemic. Many people face COVID-19 aboard super-equipped yachts adapted for a quality survival, with a certain safety and tranquility. Others live this tragedy in precarious boats, at risk of sinking at any moment. Between these two extremes there are infinite variations. Human differences are essential to understand the ways our psyche works and, consequently, our creativity. When we look at a student without a computer and internet, compared to another with state-of-the-art equipment and technology, both dealing with remote learning, for example, we find huge differences to be investigated in order to understand how subjects migrate from unpredictable and borderline situations to creative possibilities.

The way creativity develops, in moments of profound human fragility, seems to be an aspect still little explored in the literature. In this article, we seek to listen to students in their complaints, their pains, their needs, their victories, successes and failures in facing a pandemic, in a country in generalized crisis and with the obligation of studying in remote mode. This effort to understand may generate future empirical studies that deepen the investigation of the ideas discussed here. In any case, if we have come this far, it is only because of our creativity, of the enormous capacity that human beings have to transform unpredictability into possibility. Many times, these are possibilities that generate creative acts for the common good of humanity.

\section{References}

ABED (2020). Censo EAD - BR 2019-2020. Relatório analítico da aprendizagem à distância no Brasil. São Paulo: Associação Brasileira de Educação à Distância.

Aprile, M.R., \& Barone, R.E.M. (2009). Educação superior: Políticas públicas para inclusão social. Revista @ mbienteeducação, 2(1), 39-55.

Barreto, A.C.F., \& Rocha, D.S. (2020). COVID-19 e educação: Resistências, desafios e (im)possibilidades. Revista Encantar - Educação, Cultura e Sociedade, 2, 01-11.

Berg, J., Vestena, C.L.B., \& Costa-Lobo, C. (2020). Criatividade e autonomia em tempo de pandemia: Ensaio teórico a partir da pedagogia social. Revista Internacional de Educación para la Justicia Social, 9, 1-13. 
Castillo-Vergara, M., Galleguillos, M.B., Cuello, L.J., Alvarez-Marin, A., \& Acuña-Opazo, C. (2018). Does socioeconomic status influence student creativity? Thinking Skills and Creativity, 29, 142-152.

Cohen, A.K. \& Cromwell, J.R. (2021). How to respond to the COVID-19 Pandemic with more creativity and innovation. Population Health Management, 24(2), 153-155.

Cooper, H., et al. (1996) The effects of summer vacation on achievement test scores: A narrative and metaanalytic review. Review of Educational Research, 66(3), 227-268. https://journals.sagepub.com/doi/10.3 $102 / 00346543066003227$

Cornejo, C., Marsico, Giuseppina \& Valsiner, J. (Eds.). (2018). I activate you to affect me. Charlotte, NC: IAP - Information Age Publishing Inc.

Couto, E.S., Couto, E.S., \& Cruz, I.M.P. (2020). Educação na pandemia da COVID-19. Educação. Interfaces Científicas, 8(3), 200-2017. https://doi.org/10.17564/2316-3828.2020v8n3p200-217

Crawford, J., Butler-Henderson, K., Rudolph, J, Malkawi, B., Glowatz, M., Burton, R., Magni, P.A., \& Lam, S. (2020). COVID-19: 20 countries' higher education intra-period digital pedagogy responses. Journal of Applied Learning \& Teaching, 3(1), 1-20.

Duarte, N. (2011). Vigotski e o aprender a aprender. Crítica às apropriações neoliberais e pós-modernas da teoria vigotskiana. Campinas: Editora Autores Associados.

Glăveanu, V.P. (2014). Distributed creativity: Thinking outside the box of the creative individual. Cham: Springer.

Glăveanu, V.P. (2015). Creativity as a sociocultural act. Journal of Creative Behavior, 49(3), 165-180.

Glăveanu, V.P. \& Neves-Pereira, M.S. (2020). Psicologia cultural da criatividade. In M.S. Neves-Pereira \& D.S. Fleith (Eds.), Teorias da Criatividade, (pp. 141-168). Campinas: Editora Papirus.

Hodges, C., Moore, S., Lockee, B., Trust, T., \& Friday, A.B. (2020). The Difference Between Emergency Remote Teaching and Online Learning. Educause Review. https://er.educause.edu/articles/2020/3/the-difference-between-emergency-remote-teaching-and-online-learning

Kaufman, J.C., Glăveanu, V.P., \& Baer, J. (Eds.). (2017). Handbook of creativity across domains. London: Cambridge University Press

Maia, B. R., \& Dias, P. C. (2020). Ansiedade, depressão e estresse em estudantes universitários: o impacto da COVID-19. Estudos de Psicologia, 37, e200067. https://doi.org/10.1590/1982-0275202037e200067

Mattson, D.; Mathew, K.; \& Buonincontro, J. K. (2021). Media analysis of news articles during COVID-19: Renewal, continuity and cultural dimensions of creative action. Frontiers in Psychology, v. 11, 1-12.

MEC. (2020). Portaria n. ${ }^{\circ}$ 343, de 17 de março de 2020. https://www.in.gov.br/en/web/dou/-/portaria-n-343de-17-de-marco-de-2020-248564376 (Accessed on March 5th, 2021).

MEC. (2021). Ações do MEC em resposta à Pandemia do COVID-19. http://portal.mec.gov.br/index.php?option=com_docman\&view=download\&alias=183641-ebook\&category_ slug $=2020 \& \mid$ temid $=30192$ (Accessed on March 5th, 2021).

Melo, C., \& Cabral, S. (2020). A grande crise e as crises brasileiras: o efeito catalizador da Covid-19. Gestão $E$ Sociedade, 14(39), 3681-3688. https://doi.org/10.21171/ges.v14i39.3259

Monteiro, S.S. (2020). (Re)inventar educação escolar no Brasil em tempos da COVID-19. Revista Augustus, 25(51). 237-254.

Neves-Pereira, M.S. (2020). Possible in education. In V.P. Glăveanu (Ed.), The Palgrave Encyclopedia of the Possible (pp. 1-7). Springer. https://doi.org/10.1007/978-3-319-98390-5_77-2

Neves-Pereira, M.S. (no prelo). Contributions of cultural theories to the development of creativity in school. In M.S. Neves-Pereira \& A.U. Branco (Eds.). Cultural psychology goes to school. Charlotte, NC: IAP - Information Age Publishing Inc.

Py, F., Shiota, R., Possmozer, M. (2020). Evangélicos e governo Bolsonaro: Aliança nos tempos de COVID-19. Confluências. Revista Interdisciplinar de Sociologia e Direito, 22(2), 384-406. https://doi.org/10.22409/ conflu.v22i2.43024 
Reimers, F.M. \& Schleider, A. (2020). A framework to guide an education response to the Covid-19 Pandemic of 2020. OECD.

Runco, M. (1994). Problem finding, problem solving, and creativity. New Jersey: Ablex Publishing Corporation.

Saraiva, K.; Traversini, C.; \& Lockmann, K. (2020). Education in times of COVID-19: remote teaching and teacher exhaustion. Práxis Educativa, 15, e2016289, 1-24. https://doi.org/10.5212/PraxEduc.v.15.16289.094

Shadmi, E., Chen, Y., Dourado, I. et al. (2020). Health equity and COVID-19: global perspectives. Int J Equity Health, 19(104), 1-16. https://doi.org/10.1186/s12939-020-01218-z

Unicef. (2020). Key Messages and Actions for COVID-19 Prevention and Control in Schools. Available in: https:// www.who.int/docs/default-source/coronaviruse/key-messages-and-actions-for-covid-19-preventionand-control-in-schools-march-2020 (Accessed on March 2, 2021)

Valsiner, J. (2014). An invitation to cultural psychology. London: Sage.

Vygotsky, L.S. (1978). Mind in society. Cambridge, MA: Harvard University Press.

Vygotsky, L.S. (2012). Thought and language, revised and expanded edition. Cambridge, MA: MIT Press.

Wenczenovicz, T.J. (2020). Ensino a distância, dificuldades presenciais: Perspectivas em tempos de covid-19. RIAEE - Revista Ibero-Americana de Estudos em Educação, 15(4), pp. 1750-1768. https://doi.org/10.21723/ riaee.v15i4.13761

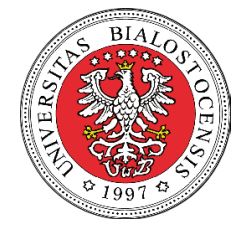

(c) Copyright by Faculty of Education, University of Bialystok,

20 Swierkowa St., 15-328 Bialystok, Poland

tel. +48857457283

e-mail: creativity@uwb.edu.pl

http://www.creativity.uwb.edu.pl 